\title{
Liturgia monetária em Cirene no século IV a.C. ${ }^{1}$
}

Daniela Bessa Puccini (*)

PUCCINI, D.B. Liturgia monetária em Cirene no século IV a.C.. R. Museu Arq. Etn., 25: $61-82,2015$

Resumo: É um lugar-comum nos estudos numismáticos, considerar que os nomes de personagens presentes nas moedas gregas eram de magistrados encarregados da produção monetária nas diversas polis ${ }^{2}$. Este artigo apresenta uma síntese da pesquisa empreendida no âmbito de um doutorado em Arqueologia e História, que propõe discutir a função que estes personagens desempenharam na cunhagem de Cirene em período clássico a partir do cruzamento entre documento numismático e epigráfico e o levantamento do contexto histórico-arqueológico em que as moedas foram produzidas. Irregularidades na análise de ligação de cunhos, que atestam a contemporaneidade das emissões, sinalizam que estes nomes não obedeciam a uma sucessão de magistrados no cargo em intervalos regulares e reforçam a hipótese de que se tratavam de doadores de metal para a produção monetária da pólis.

Palavras-chave: Cirenaica, Numismática grega, Epigrafia grega

\section{Introdução}

A partir do século IV a.C. - e ainda mais Aintensamente ao longo do período helenístico -, observamos nas diversas pólis gregas uma crescente dependência das cidades nas contribuições feitas na esfera pública

1 Este artigo origina-se na tese de doutorado "Autorità emit tente e liturgia monetale a Cirene nel IV secolo a.C", realizada na Università degli Studi di Messina (Itália), sob a orientação da Profa. Dra. Maria Caccamo Caltabiano, com bolsa CAPES de doutorado pleno no exterior.

2 Neste artigo, a terminologia em grego será grafada de acordo com padronização adotada no glossário do Labeca/MAE-USP. (ID: http://labeca.mae.usp.br/pt-br/glossary/ ). Acesso em: 8 dez. 2014.

${ }^{*}$ ) Università degli Studi di Messina. <danipuccini@gmail. com / danipuccini@mae.usp.br> por cidadãos ricos ou mesmo por monarcas helenísticos. O termo liturgia, a partir do final de época clássica na Grécia, referia-se a todos os serviços públicos cujos custos provenientes do ofício ficavam sob a responsabilidade de quem o assumisse. E se no século IV a.C. encontramos este tipo de contribuição em seu estágio embrionário, observamos pelas fontes epigráficas que nos séculos III e II a.C. o termo passou a ser aplicado para definir propriamente um cargo, arché, ou mesmo uma atividade pública, epimeleia. (Hakkarainen 1997: 31-2)

Em Cirene, mesmo que a liturgização de cargos magistratuais seja atestada somente a partir de período helenístico, observa-se que, a partir da primeira metade do século IV a.C., intensificam-se as ofertas votivas de aristocratas cireneus em benefício das obras públicas da cidade. Observa-se que não se tratam de doações casuais; essas doações de monumentos ou par- 
tes deles e da escultura decorativa endereçados à divindade políade são parte de um grande projeto de renovação urbanística da cidade iniciada neste século. Esta reestruturação, que beneficiou principalmente o Santuário de Apolo, mas também a ágora e outros espaços da cidade, sem dúvida requereu um envolvimento maciço dos poderes públicos, mas também o financiamento por parte de privados, como atestam as diversas inscrições com dedicatórias em nome desses ricos cidadãos.

$\mathrm{O}$ uso de inscrever os nomes sobre suportes diversos atingiu também a produção monetária. Sobre as moedas observa-se que a partir do início do século IV a.C. começam a ser inscritos nomes de personagens, por inteiro ou abreviados, no nominativo ou no genitivo, substituídos no fim do século IV a.C. por monogramas. Através de um levantamento das inscrições epigráficas publicadas entre o final do século V e o início do século III a.C., observou-se que alguns destes nomes estavam presentes em documentos oficiais nos quais eram listados os cidadãos que assumiam cargos de alto nível nas magistraturas da cidade, muitos dos quais membros de relevo do exército cireneu. Eles estavam presentes também sobre as dedicatórias inscritas nos monumentos - e sobre bases de esculturas destinadas a decorar os monumentos -- construídos ou reconstruídos durante esta renovação urbanística.

A moeda, neste momento, diferentemente dos períodos precedentes e posteriores, passa a representar modelos icônicos muito diversificados e foram produzidas em dois metais, em ouro e prata, e em dois padrões diversos, o ático e o asiático ${ }^{3}$ - o bronze foi introduzido somente em torno à chegada de Ptolomeu.

Para que a análise da documentação fosse completa, este estudo deveria compreender as emissões de Cirene até a metade do século III a.C. Neste primeiro momento, no entanto, o horizonte cronológico foi reduzido ao século

3 O padrão ático é baseado na dracma euboico-ática de 4,3g com tetradracma, de 17,44g; o asiático, também conhecido como ródio, tem a dracma de 3,4g e o tetradracma de 13,6g. (Morkholm 1991: 9; Breglia 1964: 120)
IV a.C., e em particular até a morte de Ofelas em uma expedição contra Cartago em torno a 310-308 a.C. (Diodoro XX, 3-40; Justino XXII, 7, 4). A partir desta data, embora ainda se atestasse o financiamento de obras públicas por privados, verifica-se uma mudança no quadro político que se reflete na cunhagem de Cirene. As moedas apresentam então uma mudança no aspecto ponderal e iconográfico, resultante de uma influência ptolomaica mais efetiva. Com a transformação política e econômica operada com a inserção de Cirene no âmbito dos reinos helenísticos é que os nomes dos personagens inscritos sobre as moedas são substituídos por monogramas, e obviamente tratam-se de personagens diferentes daqueles atestados precedentemente.

Um estudo dirigido à resolução da problemática envolvida na presença de nomes de personagens sobre as moedas torna possivel desenhar um quadro bastante claro dos protagonistas da vida pública cireneia, mesmo que não estivessem presentes os patronímicos. Mas acima de tudo contribui para a compreensão dos mecanismos envolvidos na construção de um sistema sócio-político no qual os aristocratas, como forma de afirmação do seu poder, envolveram-se diretamente nos assuntos de interesse da cidade.

Já Sandro Stucchi (1975 : 90-1, n. 3) havia acenado que:

$$
\text { (...) assim como acontece para a }
$$

doação de monumentos, quando sobre as moedas estão presentes nomes de personagens de destaque da aristocracia cireneia, estamos diante de doação de metais feita à cidade por parte de privados.

A mesma opinião foi expressa por Laronde (1987, passim), Pernier (1935, passim) e Bousquet (1952, passim) nos seus estudos epigráficos.

No âmbito da numismática, existe uma generalização de que os nomes presentes sobre as moedas gregas se referiam a magistrados encarregados da emissão monetária da pólis naquele período. Esta afirmação era calcada no princípio de que o uso do genitivo nos nomes inscritos nas moedas subentendia a presença da preposição غ̇ंı e indicava o magistrado a cargo da emissão (Lenormant 1879). Este estudo, no 
entanto, previa somente uma análise da legenda, sem levar em conta a atividade propriamente da oficina monetária e o contexto histórico-institucional em que a produção monetária se inseria.

O que faltava, portanto, no caso das emissões de Cirene, era um estudo numismático sistemático direcionado à verificação de tal hipótese. Robinson, no catálogo do British Museum (1927: ccxxxi-ccxxxiii), sustentava que aqueles nomes se referissem a "moedeiros independentes”. Ele, no entanto, não aprofundou as suas observações e a sua proposta de classificação pressupõe que as emissões monetárias fossem efetuadas sob a responsabilidade de magistrados que se sucediam no cargo. Naville (1951: passim), que em geral seguiu a classificação feita por Robinson em seu catálogo das moedas de ouro da Cirenaica, aceitou plenamente que os nomes de personagens fossem aqueles de magistrados. Muller (Muller, Falbe, Lindberg 1860: passim), que acreditava existir uma modalidade de estado federal das cidades da Cirenaica neste período, sustentava que os personagens fossem magistrados federais.

Neste artigo, me proponho, portanto, a oferecer uma síntese da minha pesquisa de doutorado, realizada na Università degli Studi di Messina entre 2010 e 2014, período em que foi possível confrontar as diversas hipóteses sobre a função exercida pelos personagens cujos nomes estão presentes nas moedas, através da aplicação de uma metodologia numismática sistemática. $\mathrm{O}$ cruzamento entre fonte numismática e epigráfica e uma abordagem cuidadosa do cenário histórico-institucional de Cirene no século IV a.C. contribuíram na atualização da discussão sobre o financiamento privado na esfera pública e em particular sobre o financiamento de moedas nas cidades gregas.

\section{Contexto histórico-institucional}

O século IV a.C. é reconhecido entre os estudiosos de história e arqueologia da Cirenaica como um momento de grande importância para a vida e para o desenvolvimento da cidade. Cirene, da metade do século V a.C., abandonou o sistema monárquico instituído pelos
Batíadas $^{4}$ para adotar inicialmente um sistema democrático ${ }^{5}$ - com fases de governo moderado que se alternavam a momentos mais radicais antes que, em torno a 321 a.C., iniciasse a influência ptolomaica em toda a Cirenaica.

As evidências literárias sobre a situação política ao longo dos séculos V e IV a.C., somadas à epigrafia e aos dados provenientes das escavações, orientam em direção a um cenário de stasis, de ostracismo, de acordos e desacordos entre a aristocracia local e os novos protagonistas da pólis. A descoberta em 1993, na ágora de Cirene, de ostraka (Bacchielli 1994) datados no último quarto do século $\mathrm{V}$ a.C., evidenciou que pelo menos em alguns momentos estava mesmo em vigor uma democracia de tipo ateniense.

Diodoro ( XIV, 34, 3-6) apontava para uma situação de stasis em torno a 401 a.C. (Laronde 1987: 27), quando um embate entre oligarcas e democratas se concluiu com a morte de 500 entre os cireneus mais influentes da cidade e com o exílio dos mais respeitáveis. Ele conclui que, com o retorno dos exilados, um posterior combate entre as duas facções resultou na reconciliação entre as partes, que tiveram de dividir o governo da cidade.

Este passo vai ao encontro de uma passagem da Política (IV, 1319b), de Aristóteles, que acena para o problema ocasionado pelo crescimento da facção democrática, situação em que os demagogos concedem de modo indiscriminado o direito de cidadania a um grande número

4 Nome dado a uma dinastia que, na tradição de fundação narrada por Heródoto (livro IV), teve como oikista um thereu de nome Batos. O seu nome está presente também, como líder desta expedição, na Estela dos Fundadores, um documento epigráfico datado no século IV a.C. (SEG IX, 3). Theotimos, autor de uma obra sobre Cirene, apontava para a forte oposição dos aristocratas ao último dos Batíadas, e em ocasião de uma revolta alguns desses aristocratas foram mortos, outros exilados (FHG IV, 517; F.Gr.Hist. IIIB: 425 ss.

5 Heraclides Lembo afirma que depois da queda da monarquia em Cirene instarou-se a democracia (Exc. Polit. 2, 212). Sobre o modelo de democracia adotado - se um governo republicano de caráter oligárquico, ou uma democracia de tipo ateniense, ou ainda a alternância destes dois modelos ao longo do período -, vd. Napoleone 1999. 
de pessoas com o fim de incrementar o círculo de partidários. Ele conclui: "esta parece ter sido uma das causas de uma stasis em Cirene". Em seguida, ele aponta as condições necessárias para a afirmação de um governo democrático, o que pressupõe que foram colocados em prática alguns procedimentos que dariam sustento ao novo regime: "Para uma democracia deste gênero, são úteis procedimentos similares aos adotados por Clístenes em Atenas, desejando aumentar a democracia, e em Cirene os fundadores do regime popular"6.

De fato, na Estela dos Fundadores (SEG IX, 3), um decreto datado da primeira metade do século IV a.C., evidencia-se a preocupação dos descendentes dos thereus de incrementar a própria representatividade cívica. Julgando pela prescrição, certamente estava em vigor então um governo democrático: Damis, filho de Bathykles, faz uma proposta diretamente à assembleia popular, neste caso o órgão deliberativo supremo, procedimento este característico de um sistema democrático de fato. Neste documento, um decreto votado pela assembleia popular garantia aos thereus a cidadania em Cirene "conforme os pactos feitos pelos antepassados". E embora Diodoro sustentasse que a formação de um governo misto tenha criado as condições de estabilidade na cidade, a prescrição desta inscrição sinaliza para uma situação ainda não resolvida: "até a cidade se sistematizar e a democracia dos cireneus prosperar (...)"

6 Dentre os procedimentos enumerados, observa-se que o aumento de número de tribos e o sistema de misturas praticado pelas fusões e pelo dissolvimento das formas associativas precedentes digam respeito mais ao sistema clistênico (Arist. Ath. Pol. 21, 6). Talvez tenham sido praticados em Cirene, por sua vez, o aumento do número das fratrias e a redução dos cultos privados. O número de tribos não foi aumentado ao menos até a publicação do diagramma de Ptolomeu, em 321 a.C. (Bacchielli 1994, passim; Napoleone 1999, p. 99).

$7 \mathrm{Na}$ narrativa da guerra contra Tibron, Diodoro (XVIII, 19-21) faz referência a oligarcas cireneus exilados em Creta em torno de 323 a.C. Também no diagramma de Ptolomeu, de 321 a.C., é clara a referência a exilados cireneus acolhidos no Egito, que são reintegrados na politeuma (SEG IX, 1, § 10). Sobre esta e outras propostas de datação de tais testemunhos escritos, vd. Laronde 1987: 97; Chamoux 1953: 215, n. 3; Bacchielli 1975: 95, n. 3.
É possível, portanto, que a democracia em Cirene tenha alternado momentos radicais a um modelo mais moderado, oligárquico. Napoleone (1999: 99-100) propõe que até c. 401 a.C. ${ }^{8}$ fossem os oligarcas que estavam no poder. Com a stasis e a formação de um governo misto, tornaram-se mais evidentes os contrastes entre as duas facções, que levaram à prevalência de um e de outro ao longo do século IV a.C.

Esta alternância de poderes é confirmada pela presença de notáveis no diagramma de Ptolomeu (SEG IX, 1), um documento publicado em torno a 321 a.C. (Laronde 1987: 86) no qual são estabelecidas as normas da nova administração. Ainda que o corpo cívico fosse denominado politeuma $a^{9}$, e mesmo que tenha sido aumen-

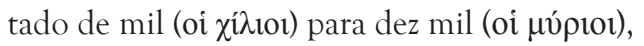
o pertencimento a esta corpo estava submetido ao censo. Isto reforça o aspecto oligárquico de Cirene e limita a participação ao direito de voto e o acesso às altas magistraturas a uma classe privilegiada, qualificando assim as pessoas para ascender aos mais altos cargos públicos da cidade, as miriakás archás (1. 45).

Mesmo que não tenhamos um documento específico que informe claramente as instituições existentes em Cirene ao longo do século IV a.C., alguns elementos do diagramma atestam que algumas delas já existiam precedentemente: aos gherontes são confirmadas as funções precedentes, em tempos de paz (§ 6); podem ser nomeados éforos "aqueles que nunca tenham ocupado o cargo" (§5).

A bulé também parece que existia precedentemente, se é verdade que a menção de Heródoto $(I V, 165)$ de que a rainha Pheretime assistia às reuniões da bulé se refira à instituição propriamente. Como observa Chamoux, a pirâmide de assembleias Eclésia - que no diagramma é

8 Bacchielli (1994: passim), com base em uma passagem de Tucídides (VII, 50), sugere que a primeira fase tenha se estendido ao menos até 413 a.C.

9 Corpo de cidadãos, que estava envolvido na administração dos negócios públicos. Como observa Dobias-Lalou (2000: 236), a palavra demos não aparece mais nas inscrições de Cirene depois da metade do século IV a.C. O uso de politeuma pressupõe que a assembleia não desempenhasse um papel significativo na adoção das leis. 
representada pela politeuma -, bulé, gherousia torna mais fácil a aprovação de iniciativas de um pequeno número de famílias, como encontramos em diversas constituições oligárquicas ${ }^{10}$. Em Cirene este controle era ainda mais efetivo visto que, a partir de uma inscrição de Euespérides (SEG XVIII, 732), supõe-se que os éforos, juntamente com a gherousia, eram responsáveis por introduzir as proposições à bulé (Chamoux 1953: 523).

Os poderes políticos, militares e jurídicos que foram transferidos do rei ao demo na Reforma de Damonax (Hdt. IV, 161), na metade do século VI a.C., sob regime monárquico, ficaram sob a responsabilidade dos éforos, estrategos e nomophylakes de período clássico (Chamoux 1953: 218). Já os dois nomothetes encarregados de redigir o diagramma foram nomeados éforos para aplicá-lo (1. 83-87). Por sinal, os dois personagens nomeados para tais funções, Pratomedes, filho de Philippos, e Androcles, filho de Callimachos, constavam coomo lochagoi monippon e lochagoi de pestaltes em uma lista militar da metade do século IV a.C. (Schwyzer 234; SGDI 4833) ${ }^{11}$. Além desta permanência dos mesmos personagens nos diversos postos de poder da cidade, observa-se também no diagramma a concessão de cargos para diversos membros dentro de uma mesma família: dos 29 nomes citados, 3 possuem o mesmo patronímico. São filhos de Etearchos ${ }^{12}$ os estrategos Kallipos (1. 76) e Theodoros (1. 77), além do nomophylax Annikeris (1. 79).

Todos estes aspectos somados retratam a manipulação dos interesses de algumas famílias mais poderosas de Cirene através de uma estruturação institucional que garantia a permanência dos mesmos personagens nos mais altos cargos do quadro cívico e militar.

10 As duas bulés de Chios; a mikrá ekklesia e a gherousia de Esparta; os Mil e a gherousia de Crotona (Glotz 1928: 98).

11 Chamoux (1953: 215-6, n. 6) estabelece esta data com base na exigência de idade superior a 50 anos para nomeação dos éforos do diagramma.

12 Nome não muito atestado em Cirene neste período. Com este nome havia o pai de um demiurgo, Etearcho (SEG IX, $25,4-5$ ), e o pai de um subscritor da grande lista do final do século ou início do III a.C., Iason Etearcho (SEG XX, 735b, I, 100). Atesta-se também em uma inscrição funerária de data indeterminada um Etearchos Menáreus (SEG IX, 216).
Mas também no âmbito religioso, o cargo reservado ao mais eminente dos cidadãos era o de Sacerdote de Apolo, uma instituição que passou para as mãos desses aristocratas provavelmente após a queda da monarquia. A gestão dos domínios sagrados de Apolo, no entanto, eram administrados por funcionários determinados, como atesta uma série de inscrições datadas entre o século V e III a.C., as contas dos demiurgos (SEG IX, 11-44), que formavam um colégio anual de três membros. ${ }^{13}$

Ainda que o diagramma ateste a adoção de uma constituição de caráter oligárquico e traços que refletem uma organização dórica, emprestada da metrópole e de Esparta, é revelador o valor retroativo da euthyna, o dever de prestar contas da própria operação no exercício de uma função pública. Este era um dos instrumentos mais eficazes de controle popular sobre a administração pública do Estado na Atenas democrática ${ }^{14}$.

Ao lado da presença dos ostraka encontrados na ágora de Cirene, que pode ser atribuída a uma influência ateniense mais efetiva, Napoleone enfatiza a intensificação dos contatos entre Cirene e Atenas a partir da metade do século $\mathrm{V}$ a.C. Este estreitamento das relações talvez esteja ligado ao controle do silfium, uma planta de propriedades medicinais e culinárias largamente exportada para as cidades gregas, em especial para Atenas, que passou ao controle dos aristocratas cireneus com a queda da monarquia, o que deve ter desencadeado um comércio ainda mais efetivo dos outros produtos da Cirenaica. Este intensificar-se do comércio pode ter uma relação ainda com o crescimento do comércio entre Atenas e a bacia oriental do Mediterrâneo promovido por Péricles depois da paz de 446/45 a.C. ${ }^{15}$ acordada pela pólis ática e Esparta. De fato, será no início do IV século que se estabeleceu em Atenas o culto de

13 Nas duas lâminas de chumbo encontradas na ágora de Cirene (Lâmina 1, A4), foi atestada também a primeira ocorrência de um iaromnámones na administração dos assuntos religiosos.

14 Sobre o procedimento de uso deste instrumento na Atenas clássica, vd. Daverio Rocchi 1993: 275-6.

15 Plut. Per. 12. 
Ammon ${ }^{16}$, exatamente quando o santuário oracular de Siwa passa a ser muito frequentado (Zorat 1990: 89-123; Napoleone op.cit.: 296). Na Estela do Envio de Cereais (SEG IX, 2), em que se atesta a prosperidade agrícola de Cirene no século IV a.C., Atenas é o principal destinatário dos $805 \mathrm{mil}$ medimnes de trigo enviados a 43 cidades gregas em ocasião da grande escassez dos anos 331-28 a.C. (Pseudo-Dem. Contra Formion XXXIV, 39, 918).

Em um documento epigráfico ateniense (IG I, 125), é testemunhada a concessão de honras da parte de Atenas a um cidadão cireneu de nome Epikerdes, que enviou ajuda financeira aos prisioneiros em Siracusa em 413 a.C. Além disso, Diógenes Laércio (Vie, doctrines et sentences des philosophes illustres, III, 20) relembra Annikeris, um notável aristocrata cireneu, como o liberador de Platão, que pagou o seu resgate em Egina em 388/7 a.C. Recordamos ainda Theodoros, um matemático cireneu que viveu em Atenas (Pl. Theet. $143 \mathrm{c}$-d) e recebeu a visita de Platão em Cirene. No mais, Atenas foi a meta do fundador da escola cireneia, Aristipos, que no diálogo com Sócrates reproduzido por Xenofonte (Mem. 2, 1, 13) refere-se ao seu exílio voluntário.

A este propósito, vale relembrar a influência que exerceu Atenas sobre os monumentos construídos depois da metade do século V a.C. em Cirene. Na ágora, a ascensão do partido democrático e o surgimento de novas funções políticas e cívicas podem ser percebidos principalmente no seu lado oeste. Ao lado do Templo de Apolo Archegeta, símbolo das leis e da ordem aristocrática, é construído o primeiro Edifício para Reuniões Públicas. O santuário arcaico de Deméter e Kore é substituído pelo edifício a paraskénia, símbolo do predomínio aristocrático e que revela em sua planta fortes ligações com edifícios atenienses (Bacchielli 1985: 3). O projeto mesmo do Olympieion, sobre a colina oriental, invocava de modo evidente o do Partenon. As semelhanças entre o templo de Cirene e aquele de Atenas são tão claras que a cronologia do primeiro não pode ser que pouco posterior ao ateniense e "certamente comportou contatos tão diretos e

16 A representação da cabeça de Zeus Ammon sobre as moedas de Cirene é atestada a partir de c. 480 a.C. até época romana. profundos para envolver e exigir aval oficial" (Bacchielli 1985: 2).

Embora exista uma relação direta entre a afirmação da democracia em Cirene e o programa de renovação urbanística, que contemplou todos os espaços públicos da cidade, foi no Santuário de Apolo que se evidenciou a necessidade de reforçar o apelo da divindade arquegueta por parte dos aristocratas. É ali que se concentra, portanto, o maior número de inscrições que fazem referência a doações que envolveram a participação de financiamento privado. Mesmo que não se perceba em Cirene uma verdadeira liturgização dos cargos públicos ainda no século IV a.C., Ensoli (2000: 65) observa que "os expoentes das mais notáveis famílias aristocráticas passaram a exercitar, através de cargos cívicos de maior relevo, um importante poder, e a sua influente ação sobre a pólis se manifestou na atividade monumental".

Merece ser recordada a dedicatória feita por Philon, filho de Annikeris, doador do mármore de Paros que recobriu o altar da divindade archegeta (SEG IX, 85-86). Também a opá do II Apollonion por parte de um grupo de aristocratas (SEG IX, 147), cujo templo foi reconstruído ex novo. Em ambos os casos, o nome de quem dedicou, no nominativo, embora não venha com especificação de cargo militar ou magistratual, atesta no verbo $\dot{\alpha} v \varepsilon \dot{\varepsilon} \theta \varepsilon \kappa \varepsilon / \alpha \grave{\alpha} v \varepsilon \varepsilon \varepsilon \kappa \alpha v^{17}$ o dom votivo feito à divindade. O objeto doado é citado: o mármore do altar e a opá.

Outra categoria atestada no santuário são as dedicatórias públicas, feitas por membros do exército que agradecem a divindade por terem obtido a primazia em uma possessão ou a décima parte de um ganho (Guarducci 1975: 2). A dedicatória é caracterizada pela presença do verbo ỏvé $\theta \varepsilon \kappa \varepsilon$ (que pode vir inclusive subentendido); o motivo, a décima parte do ganho, $\delta \varepsilon \kappa \alpha ́ \tau \alpha \nu$, no acusativo; e a divindade a quem é oferecida, $\tau \tilde{\omega} \iota$ 'A $\pi$ ó $\lambda \lambda \omega v$, no dativo. Em Cirene, essas oferendas são constituídas principalmente por um grupo de esculturas decorativas no Santuário.

Também encontramos oferendas feitas por grupos de soldados ou marinheiros. O exemplo

17 Verbo de oferta típico das inscrições votivas gregas. 
mais emblemático em Cirene é constituído pela dedicatória feita pelos estrategos que venceram a batalha contra os maques e os nassamones, dois grupos indígenas nômades que confinavam com os gregos na parte oeste da Cirenaica. A dedicatória da décima parte dedicada a Apolo foi feita através da construção do Tesouro dos Estrategos no Santuário de Apolo e a inscrição atesta a oferta feita em nome de um grupo de estrategos incisa no friso do Tesouro (SEG IX, 77). Neste caso, o verbo veio subentendido, a dedicatória no acusativo e a divindade no dativo. $\mathrm{O}$ grupo de personagens foi especificado como estrategos, e os nomes inscritos no nominativo. A proveniência da décima parte, a vitória nesta batalha, foi especificada com a preposição ảjó seguida de genitivo. ${ }^{18}$

Um documento epigráfico em particular atesta que em Cirene no final do século IV ou início do III a.C. eram praticadas as subscrições públicas (SEG XX, 735). Como outros documentos desta categoria presentes no mundo grego, consistia no levantamento de fundos com uma finalidade determinada - muitas vezes, destinados às obras públicas. Infelizmente neste caso não nos restou o fragmento que poderia esclarecer o motivo que requeria um financiamento de tal porte. De qualquer modo, é importante observar a partir deste documento que estas listas, ao misturarem os cidadãos aos estrangeiros, constituem uma etapa anterior no processo oficial de gratificação aos benfeitores, que "progressivamente levou certas cidades a atribuir oficialmente o título de everghetes tanto a cidadãos quanto aos estrangeiros" (Gauthier 1985: 21). Uma etapa que sem dúvida já era entrevista nas diversas formas de participação de financiamento privado na esfera pública na Cirene de século IV a.C.

18 Também a dedicatória feita por Aristis, filho de Philon - que doou o mármore do Altar de Apolo - pode ser enquadrada neste tipo de oferenda. Ele dedicou os espólios de uma trirreme proveniente de três vitórias navais (SEG IX, 76). O seu nome é colocado no início, sem referência à sua função nesta batalha, seguido por uma sequência em que são nomeados os seus colegas, ou seja, dois navarcos e um estratego. O espólio é oferecido a Apolo.

\section{Documento numismático}

A análise do documento numismático contempla as emissões ${ }^{19}$ autônomas de Cirene produzidas entre 435 e 308 a.C. ${ }^{20}$. No catálogo elaborado para a tese, foram incluídos 788 exemplares, em ouro e prata, em três padrões ${ }^{21}$. A partir da análise da legenda monetária, foram identificados 19 nomes de personagens, além das emissões sem nome, cuja abreviação estava condicionada à dimensão do disco metálico. Eles estavam presentes no anverso ou no reverso dependendo da denominação e da série. Quando por extenso, em geral, são inscritos no genitivo. Também há ocorrências de nomes no

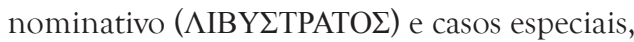
como o de Iason, em que o nome é inscrito no genitivo em duas emissões e no nominativo em uma terceira emissão de estáteres (IA $\mathrm{ONO} \Sigma \mathrm{e}$ IA $\Sigma \Omega N$ ). Os nomes são inscritos progressivos, retrógrados ou em boustrophedon. Em alguns casos, somente uma ou algumas letras são representadas retrógradas em um conjunto de letras

19 Como os catálogos mais importantes sobre as cunhagens de Cirene foram publicados até os anos 1960, foi necessário proceder a uma atualização do corpus. Neste trabalho, foram individuados 23 novos cunhos, de anverso e de reverso; a identificação de um novo personagem, $\mathrm{Ar}[$...] $]$ osios, cujo nome foi gravado sobre o cunho de um tetradracma em prata de padrão asiático, não contemplado nos estudos anteriores; e foi atribuída uma nova denominação a um personagem já conhecido - que consiste de um hemidracma em ouro de padrão ático com nome de Kydis Th.

20 Para tanto, foi realizada uma coleta dos exemplares nos catálogos das coleções numismáticas públicas e privadas e dos leilões de moedas, em relatórios de escavações, e ainda de exemplares estudados diretamente nos museus onde são conservados ou por fotografias gentilmente concedidas para esta pesquisa Aqui será fornecida a referência ao número atribuído no catálogo da tese e a referência bibliográfica

21 A partir da elaboração de gráficos ponderais, foram identificadas as seguintes denominações: Padrão ático, AV: estáter, dracma, décimo; AR: didracma, triemióbolo. Padrão asiático, AV: dracma, hemidracma; AR: tetradracma, dracma, hemidracma, triemióbolo, óbolo. Ao padrão fenício, assim denominado por Robinson (1927: cclxv-cclxvii) podem ser atribuídos os exemplares cujos pesos fazem parte de uma série de reduções empreendidas por Ptolomeu em seus diversos reinos. $\mathrm{O}$ didracma de prata em Cirene pesava entre 6,20 e $6,90 \mathrm{~g}$. 
progressivas. O mesmo vale para o étnico, que é disposto de forma bem variada. Inclusive, uma exceção ao genitivo utilizado na maioria das emissões é representado pelo uso do nominativo no estáter de ouro de Iollas (KYPANAIOE).

A partir da análise de ligação de cunhos ${ }^{22}$, evidenciou-se certa irregularidade na sequência de emissões monetárias. ${ }^{23}$ Especificamente as irregularidades consistem na utilização de um mesmo cunho contemporaneamente por diversos personagens (figs. 3 e 4). Este fato é particularmente revelador dado que, se os nomes se referissem a magistrados encarregados da cunhagem, esperava-se que esses nomes, na sequência de utilização dos cunhos, se sucedessem a intervalos regulares.

Foi possível individuar a formação de dois grupos de personagens que, por existir uma ligação entre os cunhos de anverso ou de reverso nas moedas que constam seus nomes, teriam feito essas emissões contemporaneamente ou mesmo em um período de tempo muito breve (tabela 1).

\begin{tabular}{c|c}
\hline Primeiro grupo (fig.1) ${ }^{24}$ & Segundo grupo (fig.2) \\
\hline IA $\Sigma \Omega N$ & XAIPI $($ e KYXAIPI $\Sigma$ ) \\
$\Theta E Y \Phi E I \Delta H \Sigma$ & ПO $\Sigma$ IAN $\Theta H \Sigma$ \\
KY $\triangle I \Sigma($ e KY $\Delta I \Sigma \Theta)$ & \\
\hline
\end{tabular}

Tabela 1: Grupos de personagens que teriam feito emissões contemporaneamente ou em um período de tempo muito breve.

Robinson (1927: 145) sugere que poderia tratar-se de colégios de magistrados (o que de fato existiu em Cirene, como atestam as contas

22 Metodologia de estudo numismático que consiste na reconstrução da sequência de emissão das moedas, através da análise dos cunhos de anverso e reverso utilizados na produção de uma dada série monetária. Em linhas gerais, a cronologia relativa das emissões é determinada pela combinação entre cunho de anverso e de reverso, assim como pelo nível de desgaste do cunho de anverso, especialmente.

23 Neste artigo foram expostos somente alguns dos casos mais evidentes dentre aqueles encontrados no conjunto da pesquisa.

24 Robinson (1922) e Naville (1951) consideraram Kydis Th e Kychairis como personagens diversos, embora as moedas com nome desses dois personagens estivessem ligadas pelo de demiurgos ${ }^{25}$ ). Argumenta ainda que o fato de os nomes presentes nas moedas de ouro e prata serem diferentes daqueles sobre as moedas de bronze seria mais um argumento a favor da hipótese de que se tratassem de magistrados que no caso seriam encarregados da cunhagem em metais diversos que seriam trabalhados em oficinas distantes umas das outras. ${ }^{26}$

Além do que, em dois casos em especial os nomes são acompanhados de letras que sugerem tratar-se das iniciais de outro nome ou do patronímico. Um consiste na presença das letras $\mathrm{KY}$ antecedendo o nome de Chairis - em dois cunhos de reverso. O caso de Kydis é ainda mais ilustrativo: sobre os estáteres e hemidracmas de ouro, o seu nome é acompanhado da letra theta

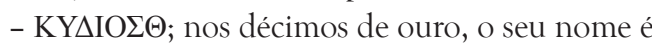
abreviado $\mathrm{KY} \Delta$ ou $\mathrm{KY} \Theta$; em todas as outras emissões consta somente o seu nome sem o theta.

Um outro fenômeno que chamou a atenção foi a existência, contemporaneamente, de exemplares sem nomes de personagens, muitas vezes ligados pelo cunho a exemplares com nome (fig. 3). Esta categoria não recebeu muita atenção por parte dos numismatas, cuja ausência foi explicada como erro por parte do gravador do cunho.

A reutilização de cunhos é sem dúvida um fato recorrente na cunhagem das cidades gregas. No entanto, neste corpus de moedas de Cirene a reutilização em um segundo momento permite que o nome do personagem seja então exposto - seja no cunho reutilizado, ou ainda em um cunho que acompanha o cunho reutilizado. $\mathrm{Na}$ cunhagem de Chairephon, por exemplo, a um cunho são adicionados em um segundo momen-

cunho às moedas de Kydis e de Chairis respectivamente.

25 Nestas contas (SEG IX, 11-44), são nomeados o Sacerdote de Apolo seguido por três demiurgos. Se a produção destas moedas com nomes estivesse vinculada à administração dos bens sagrados e vinculada à organização de jogos em honra de Apolo, se esperaria que os tipos e as legendas fossem diferentes daquelas utilizadas pela cidade.

26 Esta hipótese se deve em grande parte ao fato de que, no mundo grego, não foram descobertas arqueologicamente oficinas monetárias em que constassem vestígios de cunhagem em metal precioso. Nas poucas oficinas materialmente conhecidas atestam-se somente vestígios de produção de moedas em bronze (Camp 2001: passim). 


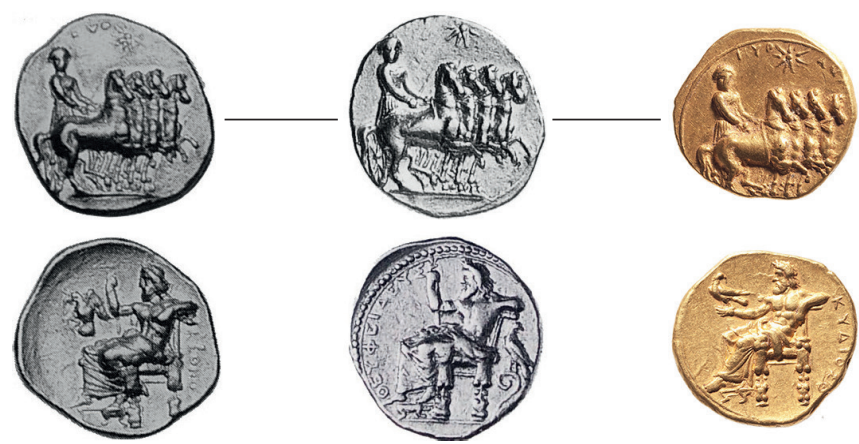

Fig. 1. Cirene, 331-308 a.C. Estáteres de ouro. O mesmo cunho de anverso (N. 4 no catálogo da tese) foi reutilizado, combinando-se a seis cunhos de reverso diversos, sobre os quais foram inscritos nomes de três personagens diferentes. Rev. N. 8: com legenda IA $\mathrm{ONO \Sigma}$ (CNG 42, 644). Rev. N. 9: $\Theta E Y \Phi E I \Delta E Y \Sigma(\operatorname{Lanz} M$ 42, 350). Rev. N. 15: KY $\Delta I O \Sigma \Theta$ (Viena 27925).

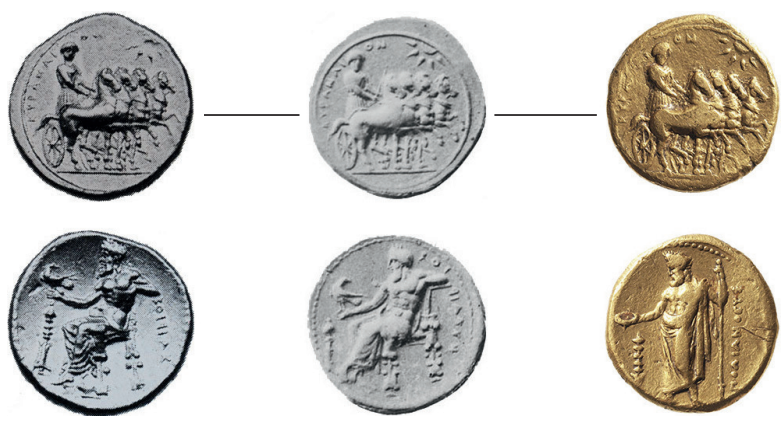

Fig. 2. O mesmo cunho de anverso (N. 12 no catálogo da tese) foi reutilizado com oito cunhos de reversos, sobre os quais foram inscritos os nomes de dois personagens diferentes. Rev. N. 25:

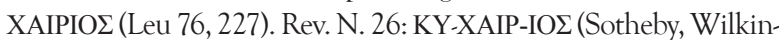

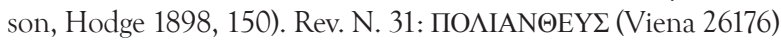

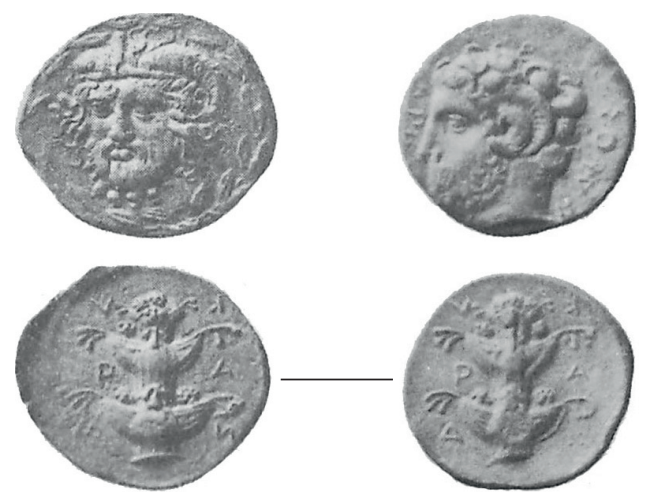

Fig. 3. Cirene, 435-375 a.C. Tetradracmas de prata. O mesmo cunho de reverso (N. 24 no catálogo da tese) foi reutilizado com dois cunhos de anverso diversos. Anv. N. 18: sem nome de personagem (BMC 77). Anv.

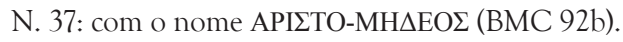


to o seu nome e o silfium (fig. 4); e na cunhagem de Iason, é adicionado o grão de trigo em um último momento da reutilização do cunho de anverso e o seu nome é disposto no cunho de reverso que acompanha este anverso (fig. 5). É importante pensarmos que esta reutilização de cunhos atesta a urgência com que as moedas foram produzidas. Isto é bastante evidente especialmente nas emissões de Polianthes, cujos cunhos de reverso são reutilizados com diversos

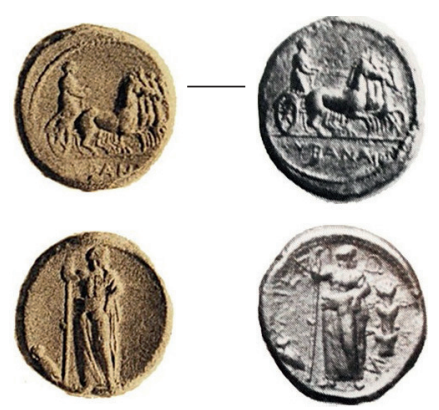

Fig. 4. Cirene, 375-331 a.C. Estáteres de ouro. Aos mesmos cunhos de anverso e de reverso (Anv. e Rev. N. 1, Babelon 1914, 3661), sobre o reverso, em um segundo momento, foi acrescentado o silfium à dir. de Zeus Ammon e a legenda com nome do personagem: XAIPE $\Phi \Omega \mathrm{N}$ (Kricheldorf 25, 135).

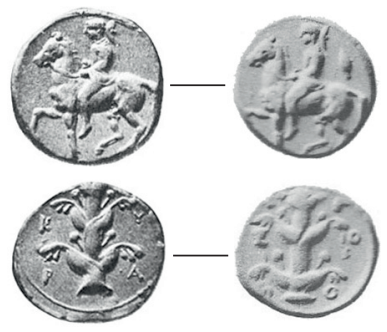

Fig. 5. Cirene, 331-308 a.C. Dracma de ouro. Ao cunho de anverso (Anv. N. 1 e Rev. N. 1 com legenda K-Y / P-A, Naville 7, 1872) foi adicionado o grão de trigo à d. do cavaleiro, e o nome do personagem é disposto no reverso (Rev. N. 2, I-A / z / I- $\Sigma$ / N-O, BMC 125a). cunhos de anverso. Como sabemos, na técnica de produção da moeda o cunho de anverso é menos exposto ao golpe do martelo durante a cunhagem, de modo que possui maior durabilidade e por isso é reutilizado com diversos cunhos de reverso. Diferentemente de uma situação de cunhagem regular, em que os cunhos de anverso são utilizados até seu total exaurimento com uma sequência regular de utilização dos cunhos de reverso, em uma situação de emergência os cunhos de reverso são utilizados com diversos cunhos de anverso em um mesmo momento (tabela 2).

No caso das moedas de Polianthes, esta reutilização desordenada dos cunhos em um mesmo momento provavelmente reflete uma situação de emergência, como uma guerra, por exemplo, em que se exigia uma produção maciça de moedas em um período muito breve ${ }^{27}$. A este respeito, podemos considerar o estudo empreendido por Le Rider sobre recunhagens efetuadas em Creta. Como ele nos informa, foram identificados cerca de $60^{28}$ moedas de prata da Cirenaica cujos discos foram reutilizados em Gortina e Festos. Foram individuados especialmente tetradracmas de padrão asiático de Cirene e de Barce, datados do século IV a.C. - dentre os quais destacamos tetradracmas do início do século (BMC pl. VIII.9) e exemplares do último quarto do século com nome de Theupheides (BMC pl. XVI.2) ${ }^{29}$-, além de didracmas de padrão ródio de Cirene, do final do século IV a.C. (BMC pl. XXIV, 1-4) Estes discos foram reutilizados em Festos e Gortina na cunhagem de estéteres de peso eginético (11,50-12 g) entre o fim do século IV e o início do III a.C. Com relação aos tetradracmas de prata, que possuem uma data mais alta do que os didracmas de padrão ródio, Le Rider sugere

27 Um caso semelhante pode ser observado na cunhagem em ouro de Dionísio de Siracusa, produzida entre o fim do século $\mathrm{V}$ e início do IV a.C., destinada ao financiamento da guerra contra os cartagineses. Vd. Bérend 1993.

28 Se considerarmos os exemplares de identificação duvidosa, este número sobe para 71. (Le Rider 1966: 143).

29 Os tetradracmas de Cirene foram utilizados na produção dos exemplares 21 a 58, pl. XIV.2-XVIII.18 de Gortina; e 38 a 59, pl. XXII.20-XXIII.22 de Festos. 


\begin{tabular}{|c|c|c|c|}
\hline \multicolumn{2}{|c|}{ Estáter } & \multicolumn{2}{|c|}{ Décimo } \\
\hline № do cunho de anverso & № do cunho de reverso & № do cunho de anverso & № do cunho de reverso \\
\hline \multirow{2}{*}{12} & $24-30$ (Chairis) & \multirow{2}{*}{18} & 34 \\
\hline & 31 (Polianthes) & & 35 \\
\hline \multirow{3}{*}{13} & 32 & \multirow{4}{*}{19} & 36 \\
\hline & 33 & & 37 \\
\hline & 34 & & 38 \\
\hline \multirow{3}{*}{14} & 32 & & 39 \\
\hline & 33 & \multirow{6}{*}{20} & 36 \\
\hline & 34 & & 37 \\
\hline \multirow{2}{*}{15} & 37 & & 38 \\
\hline & 38 & & 39 \\
\hline \multirow{4}{*}{16} & 33 & & 40 \\
\hline & 39 & & 41 \\
\hline & 40 & \multirow{4}{*}{21} & 42 \\
\hline & 41 & & 43 \\
\hline \multirow{3}{*}{17} & 35 & & 44 \\
\hline & 42 & & 45 \\
\hline & 43 & \multirow{4}{*}{22} & 42 \\
\hline \multirow{5}{*}{18} & 44 & & 43 \\
\hline & 45 & & 46 \\
\hline & 46 & & 47 \\
\hline & 47 & & \\
\hline & 48 & & \\
\hline
\end{tabular}

Tabela 2: Cunhos de reverso presentes em éstateres e décimos e cunhos de anverso a eles ligados.

que eles tenham chegado a Creta por meio dos mercenários contratados pelas cidades da Cirenaica para lutar na guerra contra Thibron, em 323-2 a.C. (Diod. XVIII, 19-21). (Le Rider 1966: 44-45; 134-46).

Para que a hipótese de um financiamento privado das moedas de Cirene sobre as quais estão presentes os nomes de personagens encontrasse um confronto, foi feito um levantamento em outras cidades gregas em cuja cunhagem se atesta a presença de nomes de personagens. Mas uma atenção especial se voltou para aquelas em

30 Todos os casos levantados datam de a partir do século IV a.C., estendendo-se pelo período helenístico. Não foram consideradas neste confronto as moedas de período romano, cuja produção de moedas era regida por uma organização institucional diversa e bastante complexa. que se observam irregularidades similares àquelas encontradas na cunhagem de Cirene e nas quais os nomes foram interpretados pelos estudiosos como de doadores de metal à cidade. ${ }^{30}$

A primeira hipótese confrontada foi a da existência de um estado federal na Cirenaica, proposta por Müller (Müller, Falbe, Lindberg 1860), caso em que os nomes presentes seriam de magistrados de cidades unidas em uma suposta federação. ${ }^{31} \mathrm{O}$ estudo empreendido por Robert Hepworth (1998), na sua classificação das emissões da Confederação Beócia do século IV a.C., foi particularmente revelador no sentido de confirmar que em uma cunha-

31 Müller baseou a sua hipótese na ausência do étnico sobre muitas das emissões deste período, o que, segundo o numismata belga, caracterizaria uma emissão federal (1860, passim). 
gem federal a regularidade presente na sequência dos cunhos caracteriza os personagens cujos nomes estão presentes sobre as moedas como magistrados. Como observou Hepworth, todos os estáteres de prata desta série (escudo micênico / ânfora) têm nomes inscritos, e muitas vezes constam também símbolos. $\mathrm{Na}$ sua análise, ele observou que 41 dos 44 magistrados presentes nos estáteres, cunhados entre 395/90 e 335 a.C. ${ }^{32}$ - uma cunhagem bastante regular -, têm suas moedas ligadas entre si pelos cunhos. Dos 160 cunhos de reversos identificados, 47 foram utilizados para cunhar duas ou mais emissões de magistrados. Ele identificou a formação de quatro grupos principais, compostos por 44 nomes de magistrados diversos. Os cunhos das emissões de cada um dos magistrados respeitam uma sucessão regular de utilização em todos os casos ${ }^{33}$, tendo sido feitas sob o controle de um e somente um magistrado epônimo por um período fixo, talvez um ano. ${ }^{34}$ Nenhuma emissão em nome de um magistrado se liga pelo cunho a emissões de um outro magistrado de um grupo diferente do seu. Significativo é também que neste caso personagens de destaque na cidade estão presentes entre estes magistrados, como Epaminondas (ЕППА / ЕППАМ(I)) (1998, p. 61) (fig.6). Da análise prosopográfica ${ }^{35}$ ele observou que os magistrados eram chefes de estado (no caso desta liga, estrategos) e estavam no cargo por um ano ou mesmo por toda a vida.

Na cunhagem de prata de Erétria (Eubeia) produzida entre 196 e 146 a.C. ${ }^{36}$, a primeira

32 Hepworth 1998: 63, n. 16. O período termina com a destruição de Tebas por Alexandre.

33 A cronologia de cada grupo foi estabelecida de modo convincente pela comparação do grau de utilização de um cunho de anverso comum (HEPWORTH 1998: 63).

34 Hepworth 1998: 62-3

35 Hepworth 1998: 37-9.

36 Head 1884 e 1887, passim. Cf. Babelon 1887: 212, que sugere uma data mais alta, entre 313 e 265 a.C. No entanto, a presença de três tetradracmas desta série no Tesouro da Babilônia 1900 (NOE 1937, n. 116) provou que a data mais baixa seria a mais provável.

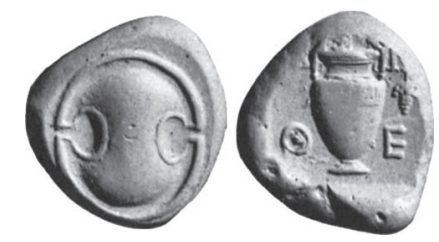

Fig. 6. Didracma de prata da Confederação Beócia com as iniciais do nome de um magistrado epônimo, The. Fonte: http://www.sylloge-nummorum-graecorum.org/ (ID: SNGuk_0404_2916). Acesso em: 20 out. 2014.

neste metal feita em nome da cidade desde a Liga de Delos, William Wallace (1959) procedeu ao cruzamento entre fonte numismática e epigráfica, mas a sua hipótese sobre o financiamento privado das emissões não encontra uma base mais consistente, que seria obtida a partir de um estudo numismático sistemático. De qualquer modo, o estudioso observou que os oito nomes presentes sobre as moedas de prata, também sem seus respectivos patronímicos, estavam presentes nas quatro denominações cunhadas neste metal e eram mencionados em documentos epigráficos deste período como benfeitores ou haviam ligação de parentesco com personagens notáveis da cidade.

Segundo o estudioso, um personagem de nome Phanias, por exemplo, poderia ser um sacerdote de Ísis, filho de Iason, honrado pelos seus fiéis neste período (op.cit.: 22). Alexipos, que ofereceu a reforma das paredes e dos emblemata dos pavimentos em mosaico do templo de Ísis, poderia ser o filho de Hagnon, um outro personagem cujo nome está presente nas moedas (op.cit.: 23).

No entanto, como foi dito anteriormente, para caracterizar uma cunhagem como resultante de um financiamento privado do metal utilizado, é fundamental que se leve em conta outros elementos, de ordem técnica, que dizem respeito ao ritmo de produção e à contemporaneidade das emissões. Os casos que mais se aproximaram dos fenômenos observados na cunhagem de Cirene foram identificados nas moedas do Novo Estilo ateniense ${ }^{37}$, assim como em Ilium, Colofon e Kabyle. Nestas cunhagens, foram os mesmos tipos de irregularidades que levaram os estudiosos a sustentarem a hipótese de liturgia monetária. 
No Novo Estilo ateniense, cunhagem feita na oficina monetária de Atenas no século II a.C. ${ }^{38}$, ainda que se tratasse de uma cunhagem anual e com um ritmo de produção bastante constante ao longo do ano, a situação entre a ligação de cunhos e a legenda monetária é bastante complexa. Todas as emissões do Novo Estilo contêm um grupo de dois ou três nomes sobre o mesmo cunho de reverso, seja em forma de monograma, por extenso ou abreviado. Margareth Thompson, em seu estudo inovador publicado em 1961 sobre as emissões em prata, observou que deste grupo de nomes um ou dois dos personagens estavam presentes na legenda monetária durante todo um ano; o último nome somente se alternava a cada mês - a indicação dos meses foi inscrita sob a ânfora que apoia a coruja no reverso das emissões.

Baseando-se na hierarquia da disposição dos nomes, a estudiosa americana propôs que os nomes que estão presentes ao longo de todo o ano são aqueles de personagens encarregados do financiamento das despesas mais consistentes das emissões anuais da cidade, enquanto aqueles que comparecem em um ou mais meses foi confiada uma parte menos pesada da despesa $^{39}$ (Thompson 1961: 594-5). E porque as séries podiam ser datadas mês a mês, é possível atestar que muitas vezes o mesmo cunho de anverso foi transferido por um grupo de personagens ao ano sucessivo, o que não constitui certamente uma novidade na cunhagem das cidades gregas. Mas em alguns casos, é surpreendente que um

37 Cunhagem produzida em Atenas em período helenístico (séc. II-I a.C.), em prata e bronze. Ao contrário da cunhagem do Velho Estilo, nestas emissões está presente a legenda com nome dos "magistrados" (ou personagens) e a indicação de mês, além de que no reverso todo o campo monetário é envolvido por uma coroa de oliveira.

38 Ainda que a datação absoluta desta cunhagem tenha sido contestada por Morkholm (1984), é o arranjo interno das emissões que dão embasamento ao seu argumento.

39 A hipótese de liturgia monetária foi proposta pela primeira vez na numismática por Beulé, em 1958, para explicar o sistema de nomes que comparecem sobre as moedas stephanophores de Atenas. A mesma opinião sobre esta cunhagem em particular foi retomada por Sundvall em 1904. Tanto Sundval como a Thompson se referem a uma "epimeleia de natureza litúrgica". dos personagens que comparecia na legenda da emissão de um ano esteja presente também no início do ano subsequente. É o caso de Kriton, cujo nome está presente no tetradracma do mês mi dos anos 142/141 a.C. (n. 721b) e no mês beta dos anos 141/140 a.C. (n. 721e). Caso se tratasse de um magistrado, certamente ele não estaria a cargo de suas responsabilidades no ano seguinte ao término de seu mandato. (Thompson 1961: 592) (fig. 7).

Em Ilium (Troas), sobre os tetradracmas emitidos a partir de 188 a.C. ${ }^{40}$ observamos um cruzamento de monogramas, nomes por extenso e símbolos que remetem ao arranjo de nomes encontrados no Novo Estilo ateniense e também uma tentativa de se hierarquizar os nomes inscritos sobre as moedas. Neste caso também se constata a utilização de um mesmo cunho de anverso com uma alternância de

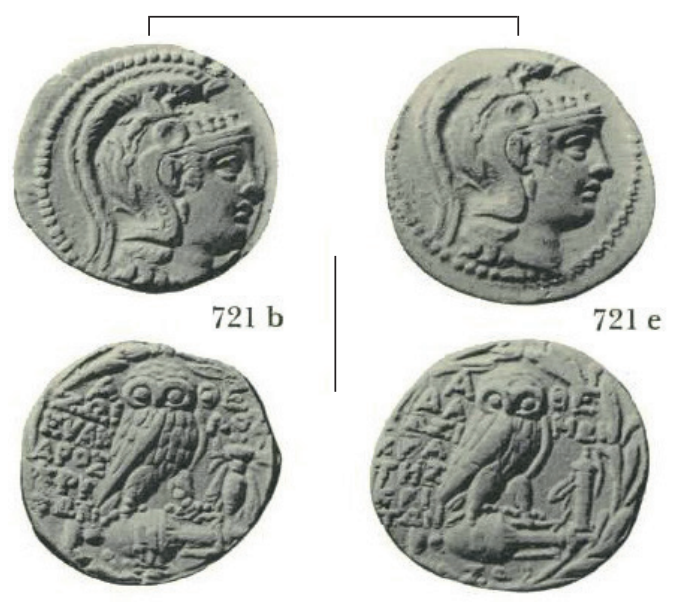

Fig. 7. Atenas, mês mi dos anos 142/141 a.C. (n. $721 \mathrm{~b}, \mathrm{Z} \Omega \mathrm{I} \Lambda \mathrm{O} \Sigma$-EYAN $\Delta \mathrm{PO} \Sigma$-KPIT $\Omega \mathrm{N}-\Sigma \Omega \mathrm{KPAT}$ ) e mês beta dos anos 141/140 a.C. (n. 721e, $\Delta \mathrm{AM} \Omega \mathrm{N}$ $\Sigma \Omega \Sigma$ IKPATH $\Sigma$-KPIT $\Omega N$ ). (Thompson 1961: $260 \mathrm{e}$ 263, pl. 77

40 A data proposta por Bellinger, além de basear-se em eventos históricos e sobre o estilo, tomou como referência o início da cunhagem do Novo Estilo ateniense. Se Margareth Thompson (1952) data o início do Novo Estilo em 196 a.C., depois da liberação da Grécia por Flaminius, o ano de 188 seria adequado como sucessivo à liberação dos gregos da Ásia em Apameia. (Bellinger 1958: 11, n. 1). 
nomes de diversos personagens no reverso. Ou seja, temos uma sequência cronológica que mostra claramente uma contemporaneidade das emissões. Em um caso particular, ocorre que o cunho de anverso foi utilizado em um primeiro momento por um personagem cujo nome é representado por um monograma juntamente com o nome de Dionisidorou; sucessivamente, com o mesmo cunho de anverso, no reverso está presente o nome de Apemantou, disposto ao lado do mesmo monograma do cunho de reverso citado; em um terceiro momento, combinado ao mesmo cunho de anverso temos no reverso o nome de Apemantou ligado a um monograma diferente daquele representado nos dois cunhos de reverso precedentes (fig. 8).

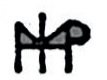

$+$

\section{$\triangle \mathrm{IONY} \Sigma \mathrm{O} \Delta \Omega \mathrm{POY}$ АПЕMANTOY}

Fig. 8: Diferentes associações entre monogramas e nomes

No caso do Novo Estilo ateniense, em cuja primeira fase da cunhagem havia também uma forma mista de representação dos nomes, por extenso e com monogramas, Thompson (1961: 546) interpretou todos os nomes, mesmo aqueles inscritos em forma de monograma, como referentes a nomes de doadores de metal. Como gradativamente os monogramas foram substituídos por nomes por extenso, ela justificou este fato como se houvesse um crescente desejo de reconhecimento de modo mais preciso e certo. No caso das moedas de Ilium, Bellinger (1958: 18) propôs que somente os personagens cujos nomes foram inscritos por extenso seriam os doadores honrados sobre as emissões que eles mesmos financiaram.

Louis Robert (1966: passim) contestou de modo agressivo as conclusões a que chegou Bellinger, alegando não ter sido levado em consideração os documentos epigráficos de Ilium deste período. Segundo o epigrafista francês, essas moedas poderiam tratar-se de emissões cívicas emitidas pela Confederação de Atena Ilias, e seria o presidente dos agonothétes que teria feito inscrever o seu nome sobre as emissões. No entanto, como argumenta acertadamente Guépin (1969: 208), a grande maioria dessas emissões têm dois nomes inscritos sobre o mesmo cunho, o que invalida a proposta de Robert, que não levou em conta, ao contrário, o próprio documento numismático.

Em Kabyle (Trácia), sobre as emissões de tetradracmas de peso ático datadas no último quarto do século III a.C. ${ }^{41}$, em grande parte das emissões é atestada a presença do nome de um personagem abreviado, inscrito sob o trono de Zeus e acompanhado de uma marca de cunhagem; há um caso somente em que o nome é inscrito por extenso - o nome Dezoz é apresentado sob o trono -, juntamente com o nome abreviado, que neste caso foi transferido para cima da cabeça de Ártemis, uma marca de cunhagem. Como em todas as outras emissões da mesma série, exceto nesta, é inscrito o nome de somente um personagem, e sempre abreviado, Gerassimov (1958) supôs que esta única exceção fosse resultante de uma concessão feita pelo governo da cidade para que o tal Dezoz inscrevesse o seu nome por extenso; a razão seria que o personagem em questão tivesse efetuado uma liturgia monetária (fig.9).

Em Colofon, nas emissões de dracmas de prata datadas na primeira metade do século IV a.C., vemos um cruzamento de utilização de cunhos bastante confuso, que atesta que estas emissões foram produzidas em um intervalo bem curto de tempo. Neste caso, um mesmo cunho de anverso foi utilizado por diversos personagens, cujos nomes foram inscritos no cunho de reverso (tabela 3).

Como podemos observar deste esquema, Hermonax e Platon do primeiro grupo se repetem no segundo grupo acompanhados inclusive de um novo membro, Pythodoros; em uma

41 Mais exatamente antes de 218 a.C. Gerassimov (1958) propôs esta data porque, entre uma das emissões, o cunho de anverso de um tetradracma foi reutilizado pelo rei gaulês, Cavarus, mediador de um tratado de paz entre Bizâncio e o rei Prusias da Bitínia e que foi morto na Revolta dos Trácios contra a dominação gaulesa. 
terceira combinação de cunhos ligados, Zenes do primeiro grupo condivide o cunho de anverso com Aristides e Nikis. Como observa Milne (1941: 26-9), não é raro que na cunhagem grega ocorra a transferência de um cunho de um magistrado a outro que ocupou o cargo no ano seguinte, ou que um grupo de três magistrados que controlam a oficina monetária tenham trabalhado sobre uma quantidade maciça de metal em um mesmo momento de modo a utilizar os cunhos desordenadamente. No caso de Colofon, no entanto, não se observa uma prioridade na utilização dos cunhos. Os nomes se alternam como se as emissões tivessem sido cunhadas em um mesmo momento e o cunho de anverso tivesse sido combinado a diversos cunhos de reverso com os nomes de diversos personagens alternados sem que se perceba uma sucessão no cargo magistratual (Milne 1941: 27-8).

Segundo o estudioso, em Colofon um grupo de subscritores pode ter financiado o metal destinado às emissões, doando de seus próprios recursos privados os meios necessários para tal e terem sido encarregados da preparação dos cunhos e da cunhagem mesma. O estudioso define tais subscritores como magistrados ad hoc, e acrescenta que isto poderia explicar a falta de nomes de magistrados nas moedas de bronze do mesmo período, cuja responsabilidade seria da pólis. (op.cit.: 29)

Também em Cirene é a ausência de nome de personagem que reforça a hipótese de financiamento privado da cunhagem, como vimos nos tetradracmas de prata com nome de Aristomedes (fig. 3), e também sobre as dracmas de ouro com nome de Iason (fig. 5), ao qual foi adicionado o grão de trigo como símbolo ao cunho já existente precedentemente sem nome.

No Novo Estilo ateniense acontece algo de muito símile. Sobre as dracmas do ano 166-5 a.C. um cunho de anverso foi combinado a dois cunhos de reverso, um com nome dos personagens e outro sem nome. Diferentemente das dracmas de Cirene em nome de Iason, as emissões que trazem como símbolo a espiga de trigo não apresentam nomes. Os mesmos cunhos de
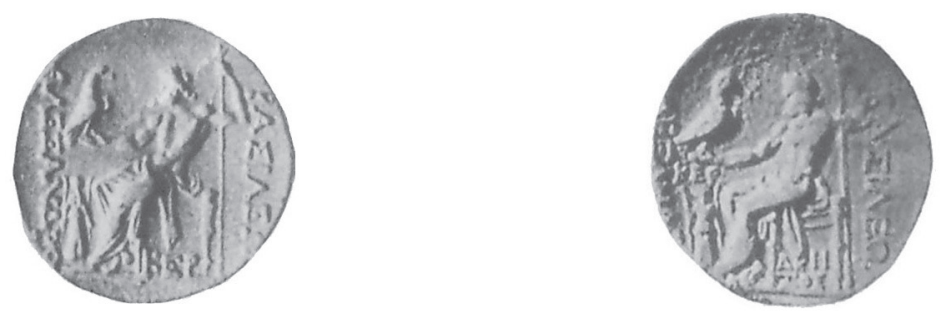

Fig. 9. Kabyle, último quarto de século III a.C. Reverso de tetradracmas de prata. À e., o nome KEP está presente sob o trono; à d., a inscrição é feita em nome de $\Delta \mathrm{H}-\mathrm{ZOZ}$ sob o trono e no campo e., KEP. (Gerassimov 1958, n. 10 e 8 , pl. XVI. 9 e 13).

\begin{tabular}{|c|c|c|}
\hline Primeiro grupo & Segundo grupo & Terceiro grupo \\
\hline EPMONAX & EPMONAX & $\mathrm{API} \Sigma \mathrm{TEI} \Delta \mathrm{H} \Sigma$ \\
\hline ZENO $\triangle \mathrm{OTO} \Sigma$ & П $\Lambda \mathrm{AT} \Omega \mathrm{N}$ & ZENE $\Sigma$ \\
\hline П $\Lambda \mathrm{AT} \Omega \mathrm{N}$ & $\Pi \mathrm{Y} \Theta \mathrm{O} \Delta \Omega \mathrm{PO} \Sigma$ & NIKIA $\Sigma$ \\
\hline ZENE & & \\
\hline
\end{tabular}

Tabela 3: Grupos de personagens que utilizaram um mesmo cunho de anverso em emissões de dracmas feitas na primeira metade do século IV em Colofon feito emissões contemporaneamente ou em um período de tempo muito breve. 
anverso, no entanto, foram utilizados no mesmo ano para produzir as emissões sobre as quais comparecem os nomes de dois personagens anuais, Timar-Nika, e daquele mensal, Arche, com a âncora como símbolo neste último caso. (Thompson 1961: 143-147) (fig. 10).

É importante sublinhar, em todos estes estudos de caso que a reutilização do cunho pressupõe a contemporaneidade das emissões, que depende da duração dos próprios cunhos. O cunho de anverso, porque é fixo e tem uma vida útil mais longa, é aquele reutilizado com diversos cunhos de reverso. É o seu nível de desgaste que determina, portanto, a sequência cronológica das emissões.

Mas quantos cunhos de reverso podem ser combinados a um mesmo cunho de anverso? No Novo Estilo ateniense temos emissões longuíssimas no mesmo ano e também um cruzamento no arranjo dos cunhos de anverso e reverso entre meses sucessivos. $\mathrm{O}$ intervalo máximo de utilização de um cunho neste caso não superou dois anos. É o caso dos cunhos das dracmas produzidas do mês alfa ao mês lambda do ano 162-1 a.C., cujo cunho de anverso foi deixado de lado e então reutilizado do mês gama ao mês theta do ano 160-59 a.C., logo dois anos depois (id.: 160-169). Obviamente a vida útil de um cunho depende do seu grau de usura. No caso da dracma citada, este cunho de anverso foi utilizado em um primeiro momento com nove cunhos de reverso, e mais os outros três cunhos de reverso que compreendem todas as emissões de dracmas daquele ano.

Estas considerações me induzem a pensar, em relação às cunhagens de Cirene, em um intervalo mais breve do que foi proposto para a produção dessas moedas, embora a ausência de novos exemplares provenientes das escavações e de tesouros impeça que seja reproposta uma cronologia absoluta. Como observamos, os grupos de personagens foram individuados com base na codivisão de um mesmo cunho de anverso. $\mathrm{O}$ caso mais emblemático é a emissão de estáteres, cujo cunho de anverso foi utilizado por Iason, Theupheides e Kydis Th (fig. 3).

Na pesquisa prosopográfica não se identificou nenhum Kydis na cidade que tivesse como patronímico um nome que iniciasse com theta. Além disso, nenhum personagem teve seu nome acompanhado de um patronímico ou de uma inicial qualquer que justificasse a presença deste theta. Como contemporaneamente um Kydis sem theta condividiu o cunho de uma série de dracmas com o mesmo Theupheides, é possivel que se trate do mesmo Kydis que usa o theta sobre alguns estáteres. Podemos sugerir ainda que o theta sobre os estáteres se refira ao nome de Theupheides - e por consequência que supostamente estamos diante de uma hierarquização de nomes com base na proporção de investimento feito por cada um dos personagens para esta emissão em particular.

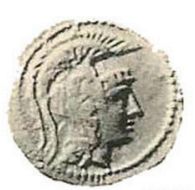

371 a

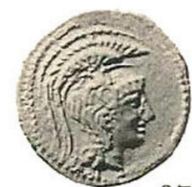

$371 \mathrm{f}$
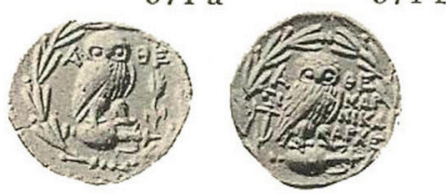
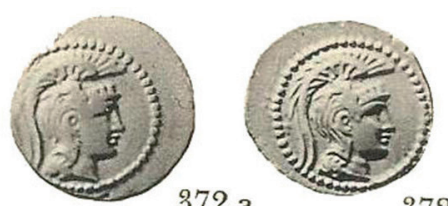

$372 \mathrm{a}$
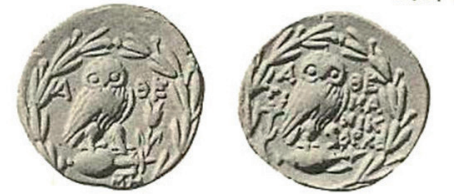

Fig.10. Atenas, 166-5 a.C. Dracmas de prata. Os cunhos de anverso 371 e 372 foram combinados a duas modalidades de cunhos de reverso: com a letra $a$, não constava nome de magistrado e o símbolo utilizado era a espiga de trigo; com a letra $f$ e $d$, os personagens TIMAP, NIKA, APXE utilizavam a âncora como símbolo. (Thompson 1961: 146, pl. 37). 
Também sobre os estáteres sobre os quais encontramos os nomes de Chairis e Polianthes podemos fazer o mesmo tipo de consideração. Nesta série, sobre dois cunhos de anverso o KY precede o nome de Chairis (Leu 36, 221; BMC 115). Neste caso não conhecemos um Chairis que pudesse ter um primeiro nome iniciado com KY. É possível que a inicial de Kydis tenha sido adicionada ao nome de Chairis. (fig. 4)

Se é verdade que estas abreviações se referem a tais personagens, que são componentes destes mesmos grupos, temos então uma ligação entre os dois grupos que evidentemente seriam contemporâneos. Neste caso, a cronologia proposta por Robinson (1927) e confirmada por Naville (1951) teria mesmo de ser revista, e o intervalo entre as emissões, que seria entre 331 a.C., para a primeira emissão de Iason do $1^{\circ}$ grupo, e 308 a.C. para a última de Polianthes, seria reduzida a poucos anos ${ }^{42}$.

Esta abordagem na interpretação da legenda monetária difere muito da afirmação feita por Lenormant (1879: 51) de que o sistema de legendas em nome de magistrados sobre as emissões do Novo Estilo ateniense responde perfeitamente ao espírito democrático ateniense, no qual todos os oficiais que administravam o fundo público tinham o seu trabalho submetido a conferência. $O$ estudioso, baseando-se nas inscrições datadas no fim do século $\mathrm{V}$ a.C., que regulava as emissões conjuntas de Mitilene e de Foceia e que previa a pena de morte para quem as falsificasse, sustentava que os nomes inscritos sobre as moedas serviam para controlar qual indivíduo estaria encarregado das emissões em caso de fraude (1879: 38). Sobre o caso específico dos estáteres de electrum da aliança comercial entre Mitilene e Foceia, Bellinger (1958: 16) recorda que sobre estas emissões às quais se refere tal inscrição epigráfica não havia legenda. Portanto, o controle rigoroso contra fraude não era feito por meio da identificação do personagem sobre a própria emissão.

Além disso, como observa ainda Bellinger (1958: 16), se a legenda monetária fosse um

$42 \mathrm{Na}$ tese foram mantidos os recortes cronológicos propostos por Robinson (1927) por falta de elementos que assegurassem uma nova proposta de cronologia absoluta para essas emissões. meio democrático de controle dos oficiais que administravam os fundos públicos, como nas emissões do Velho Estilo ateniense de V e IV séculos a.C., emitidas em pleno sistema democrático, não havia nomes de magistrados?

Qual tipo de controle podia tornar útil o nome do oficial na legenda monetária?

O controle, como supunha Lenormant (1879: 38), seria feito para evitar fraude. Recordamos que também sobre as emissões gregas em bronze estão presentes nomes de personagens. Qual tipo de fraude poderia ser feito com o bronze? Com a prata, a fraude consistiria na subtração ilegal de parte do metal confiado ao oficial encarregado de transformá-lo em moeda. Era possível, contudo, produzir moeda com alma de cobre revestida de prata. Uma outra possibilidade seria de alterar a pureza do metal. Se produziria discos com peso inferior àquele regulamentado ou um número inferior de discos em relação àqueles que se produziriam normalmente com uma quantidade determinada de metal.

Bellinger (1958: 16-8) observa que, entre estas possibilidades, a mais recorrente na antiguidade era a produção de moeda com uma película de prata sobre alma de cobre, como os denários suberati romanos. Para um oficial que trabalhava na oficina monetária seria muito difícil manter a fraude em segredo, já que não trabalhava sozinho. Ele também não seria capaz de alterar a pureza do metal, acrescentando uma quantidade superior de cobre àquela prevista, sem envolver ou sem poder contar com a cumplicidade dos outros funcionários. A solução mais prática para um oficial seria portanto não produzir a quantidade de moedas previstas para aquela quantidade de metal fornecido: é este o único caso em que ele não seria descoberto. E neste caso, a legenda não seria fundamental para o controle da fraude.

O único modo útil de controle das emissões, de fato, seria a contagem das moedas logo que foram cunhadas, o que responde muito bem ao espírito democrático ateniense. Neste sentido, uma prática a que todos os magistrados que manejavam os fundos públicos estavam submetidos era à euthyna, a conferência no final do mandato.

Thompson (1961: 546 ss.), que efetuou uma análise prosopográfica dos nomes dos personagens presentes sobre as emissões, notou que 
estes personagens, além de terem participado de liturgias de diversos tipos, ocuparam cargos de alto nível na qualidade de embaixadores, theoroi, estrategos. A estudiosa em particular observa que é difícil imaginar os notáveis da cidade na tarefa de inspetores da oficina monetária. Isto implicaria que eles deveriam supervisionar todas as fases da operação, da refinação do metal à cunhagem da moeda. Um trabalho deste gênero, além de ser muito duro, teria requerido o conhecimento de uma arte muito específica, típica de uma profissional altamente especializado.

\section{Prosopografia e conclusão}

A partir de uma contextualização de Cirene em período republicano, da análise de ligação de cunhos, do confronto com cunhagens de outras cidades em que nomes presentes nas moedas foram interpretados como de personagens que doaram metal à cidade, e ainda de um estudo prosopográfico ${ }^{43}$ feito a partir dos documentos epigráficos de Cirene datados entre a metade do século V e o início do III a.C., os resultados a que cheguei me levam a concluir que tais personagens possam ser interpretados como doadores de metal. Alguma cautela certamente se deve ter nesta afirmação, já que os patronímicos não estavam presentes nas moedas, além de que alguns dos nomes eram bastante recorrentes nas inscrições de Cirene deste período.

Sugiro de qualquer maneira a identidade de alguns dos personagens. Neste sentido vale a pena recordar o papel desempenhado por Melanippos e dos membros de sua família. O nome de Melanippos foi inscrito sobre dracmas de ouro de padrão ático: ele poderia ser o sacerdote de Apolo que doou o revestimento marmóreo do reservatório de água da Fonte de Apolo em 335 a.C. (ASA 39-40, n. 183). Ele seria portanto o pai de Kallipos, definido estratego no diagramma de Ptolomeu (SEG IX, 1), e também de Policlés, atleta vencedor em Olímpia em 348 a.C. (Diod. XVI, 53, 1), triacatiarca em 345 a.C. (Schwyzer 234) e

43 Este estudo foi feito a partir de um levantamento das ocorrências de tais nomes em: Bechtel 1917; Corsten 2010; Fraser, Matthews 1987; Marengo 1991. talvez éforo no diagramma. Ele é também o avô de um tal Policlés que está presente na longa lista de subscritores do final do século (SEG XX, 735).

Assinalo ainda a família de Aristis, cujo nome foi inscrito sobre tetradracmas de prata de padrão asiático. É possível que Aristis seja o personagem que fez a oferenda das trirremes em ocasião de uma vitória naval, em torno a 330 a.C. (SEG IX, 76). Este personagem, portanto, seria o neto de Annikeris, que pagou o resgate de Platão em Egina em 388 a.C. (Diog. Laercio, Vida dos Filósofos Ilustres, III, 20); e o filho de Philon, triacatiarca e estratego depois da metade do século IV a.C. (Schwyzer 234), que contribuiu de modo significativo na renovação do Santuário de Apolo (SEG IX, 85-86).

Polianthes, cujo nome está presente nas moedas em ouro e prata em padrão ático, poderia ser o estratego nomeado no diagramma, filho de Eukleidas, que foi theoros em Delfos (SEG XX, 707) e sacerdote de Apolo (SEG IX, 13). O seu irmão seria o notável sacerdote Praxíadas, que financiou a construção dos Propileus do Santuário da Myrtousa (ASA 39-40, n. 129).

No século IV a.C. a liturgia era um condição de participação na vida pública da cidade e em particular o financiamento da guerra era um modo de obter prestígio social e reconhecimento político: ao lado das despesas para equipar uma frota, por exemplo, um modo de contribuir para o financiamento da guerra podia ser a doação de metal para a cunhagem de moedas (Hakkarainen 1997: 10). Já a estudiosa Margareth Thompson (1961: 546 ss.) acenou no seu estudo sobre o Novo Estilo ateniense à contribuição dos personagens que ocupavam cargos diversos e que assumiam a responsabilidade pelo financiamento de uma das vozes de despesas da cidade, que era a produção de moedas. Deste modo, também um estratego podia ser responsável por esta despesa, obtendo em troca que o seu nome fosse inscrito sobre as emissões como forma de gratidão por parte da cidade.

Às vezes, a despesa requeria um capital maciço e era por isso necessário que o financiamento fosse dividido entre diversas pessoas não suficientemente ricas para efetuá-lo sozinhas. Se isto requeria a intervenção seja de outros personagens ilustres, seja de amigos ou 
familiares, então encontramos uma possível explicação à contemporaneidade na utilização dos cunhos da parte de diversos personagens. Neste sentido, portanto, talvez as emissões nas quais não se atesta a presença de nome de personagem poderiam ser aquelas na qual se sublinha a participação da cidade, como acontece também nas emissões feitas exclusivamente em nome da cidade, sem referência aos personagens.

Poderia tratar-se enfim de liturgia monetária e uma confirmação poderia ser a ausência do nome de Chairephon e de Iollas nas inscrições da Cirenacia: isto poderia parecer um argumentum ex silentio; na verdade tal ausência poderia sugerir que se tratem de estrangeiros. As contribuições de estrangeiros nas cidades não foram raras. De fato, fazer-se benfeitor era um dos modos de se adquirir o direito de cidadania (Hakkarainen 1997: 11-12). O nome dos dois personagens estão presentes sobre os estáteres em ouro de Cirene. Iollas é um nome bastante raro nas inscições das outras cidades do Mediterrâneo no século IV a.C.; encontramos um na Macedônia (Hatzopoulos, p. 93-4, n. 79, 11) e um outro em Kasos, no Dodecaneso (IG XII $\left.{ }^{1}, 1053\right)$. Chairephon, ao invés disso, é um nome muito frequente na Atenas de IV século a.C. (Fraser; Matthews 1994: 471) e recordamos com relação a este ponto que é justamente sobre o estáter em ouro que tem seu nome no qual encontramos também a coruja, símbolo da cidade de Atenas (fig. 6). Concluindo, Libystratos, nome inscrito sobre um tetradracma, é um unicum: o seu nome, de fato, não está presente em nenhuma inscrição. Trata-se de um nome falante, como foi sugerido por Sandro Stucchi (1975: 90-1, n. 3), cujo significado tem uma clara referência à armada líbica.

\section{Agradecimentos}

Agradeço à minha orientadora do doutorado, Prof. Maria Caccamo Caltabiano, cujo vasto conhecimento em numismática e atenção a mim concedida me possibilitaram a realização de um estudo sistemático como este. Ao Prof. Nicola Bonacasa, da Università degli Studi di Palermo e diretor da Missão Arqueológica desta universidade em Cirene, da qual participo desde 2008, agradeço pelo auxílio científico e apoio constante. Parte desta pesquisa foi realizada no âmbito de um programa oferecido pela Scuola Archeologica Italiana di Atene aos doutorandos das universidades conveniadas italianas, do qual participei por dois anos. Dirijo aqui especial agradecimento ao diretor da Scuola, Emanuele Greco, e aos seus professores, que colaboraram para o desenvolvimento da pesquisa.

PUCCINI, D.B. Monetary liturgy at Cyrene in the IV BC. R. Museu Arq. Etn., 25: 6182,2015

\begin{abstract}
It is a common place in numismatic studies to consider that the names of the persons seen in the Greek coins were related to magistrates charged of coin production in different "polis". This article presents a synthesis of a $\mathrm{PhD}$ research in Archeology and History and it is aimed at discussing the role the aristocrats had in striking coins in Cyrene during the classical period. It was possible due to crossing numismatic and epigraphic sources and also the historical and archeological context in which the coins were made. Irregularities in the analysis of die links, that show emissions contemporaneity, point that these names do not follow a succession of magistrates charged at regular intervals and reinforce the hypothesis that these are related to people who donated metal for the monetary production of the "polis".
\end{abstract}

Keywords: Cirenaica, Numismática grega, Epigrafia grega 


\section{Referências Bibliográficas}

Aristóteles. Politica. A cura di Carlo Augusto Viano. Milano, 2002. (Classici Greci e Latini.)

ASA 1962-1963. Supplemento Epigrafico Cirenaico. Annuario della SAIA 39-40 : 219-375.

Babelon, E. 1887. A Tetradrachm of Eretria, Revue Numismatique 3.3.

Bacchielli, L.1985. Modelli politici e modelli architettonici a Cirene durante il regime democratico. In Reynolds J. (ed.), Cyrenaica in Antiquity. Papers presented at the colloquium on society and economy in Cyrenaica, Cambridge March-April 1983. Oxford, p. $1-14$.

Bacchielli, L.1994. L'ostracismo a Cirene, RFil 122, 1994, p. 257-270.

Bacchielli, L., Bonanno Aravantinos, M. (ed.). 1996. Scritti di antichità in memoria di Sandro Stucchi, Studi Miscellanei 29, v. 1.

Bechtel, Fr. 1917. Die historischen Personennamen des Grieschischen bis zur Kaiserzeit. Halle (reimpr. Hildesheim; Zürich; New York, 1982).

Bellinger, A.R. 1958. The first civic tetradrachms of Ilium, ANSMN VIII, p. 11-24.

Bérend D. 1993. Le monnayage d'or de Syracuse sous Denys I. In La monetazione dell'età dionigiana. Atti dell'VIII convegno del Centro Internazionale di Studi Numismatici (Napoli 1983). Roma: Istituto Italiano di Numismatica, p. 91-143 e pl. 4-11.

Bonacasa, N.; Ensoli, S.; Baldassarre, I. (ed.). 2000. Cirene. Milano: Electa.

Bousquet, J.; Fomine Y. 1952. Le trésor de Cyrène. Paris. (École Fran aise d'Athènes, Fouilles de Delphes 2).
Camp, J.; Kroll, J.H. 2001. The Agora Mint and Athenian Bronze Coinage, Hesperia 70, pp. 127-162.

Chamoux, F. 1953. Cyrène sous la monarchie des Battiades. Paris : E. de Boccard.

Corsten, T. (ed.). 2010. A Lexicon of Greek Personal Names. Vol. V: Costal Asia Minor: Pontos to Ionia. Oxford University Press.

Daux, G. 1963. Note sur une inscription de Cyrène, in BCH, LXXXVII, pp. 388-90.

Demostenes (PS). Plaidoyers politiques. Trad. Octave Navarre e Pierre Orsini. Paris, 1972.

Diodoro Sículo. Biblioteca Storica. Libri I-VIII. Trad. Marta Zorat e Giuseppe Cordiano. Milano, 1998.

Diodoro Sículo. Biblioteca Storica. Libri XIV-XVII. Trad. Teresa Alfieri Tonini. Milano, 1985.

Diodoro Sículo. Biblioteca Storica. Libri XVIII-XX. Trad. Anna Simonetti Agostinetti. Milano, 1988.

Diógenes Laércio. Vie, doctrines et sentences des philosophes illustres. Trad. Robert Genaille. Paris, 1933.

Dobias-Lalou, C. 2000. Le dialecte des inscriptions grecques de Cyrène, Kartago XXV.

Ensoli, S. 2000. L'Agorà. In Bonacasa, N; Ensoli, S.; Baldassarre, I. Cirene, Milano: Electa, pp. 59-80.

Fraser, P.M.; Matthews, E. (ed.). 1987. Lexicon of Greek Personal Names. Vol. I: Aegean Islands, Cyprus, Cyrenaica. Oxford University Press.

Gasperini, L. 1987. Le laminette plumbee iscritte dal ripostiglio dell'agorà di Cirene, 
Giornata Lincea sull'Archeologia Cirenaica. (Atti dei Convegni Lincei 87).

Gauthier, P. 1985. Les cités grecques et leurs bienfaiteurs. Athènes/Paris. (Bulletin de Correspondance Héllénique, Supplément XII).

Gerassimov, Th. 1958. The Alexandrine tetradrachms of Cabyle in Thrace, AN SCent, p. 273-77.

Guarducci, M. 1975. Epigrafia Greca III: Epigrafi di carattere privato. Roma: Instituto Poligráfico.

Guépin, J. P. 1969. De Novis Libris Iudicia: Robert L., Monnaies antiques en Troade, Paris, 1966. Mnemosyne, serie IV, v. 22, fasc. 1, pp. 207-12.

Hakkarainen, M. 1997. Private Wealth in the Athenian Public Sphere during the Late Classical and the Early Hellenistic Period. In Frösén, J. Early Hellenistic Athens: Symptons of a Change. Helsinki: Foundation of the Finnish Institute at Athens. pp. 1-32.

Hatzopoulos, M.I. 1996. Macedonians Institutions under the Kings. Athens: Diffusion de Boccard.

Head, B. V. 1884. British Museum Catalogue of Greek Coins, Central Greece. London: Forni.

Head, B. V. 1887. Historia Nummorum: A Manual of Greek Numismatics. Oxford University Press.

Hepworth, R. 1998. The 4th Century BC Magistrate Coinage of the Boiotian Confed-

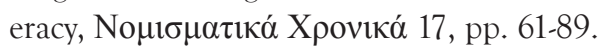

Heródoto. Le Storie. Vol. IV: Libro IV, La Scizia e la Libia. Trad. Augusto Fraschetti. Milano, 1993. (Scrittori greci e latini.)

IG XII, 3 = Hiller von Gaertringen F. (ed.). 1898. Inscriptiones Graecae XII, 3. Inscriptiones Symes, Teutlussae, Teli, Nisyri,
Astypalaeae, Anaphes, Therae et Therasiae, Pholegandri, Meli, Cimoli. Berlín.

IG XIV = Kaibel G. (ed.). 1890. Inscriptiones Graecae XIV. Inscriptiones Siciliae et Italiae, additis Galliae, Hispaniae, Britanniae, Germaniae inscriptionibus. Berlín.

Justino. Histoires Philippiques de Trogue Pompée. Trad. E. Chambry e L. Thiély-Chambry. Paris, 1936.

Laronde, A. 1987. Cyrène et la Libye Hellénistique. Libykai Historiai de l'époque républicaine au principat d'Auguste. Paris: Éditions du Centre National de la Recherche Scientifique (Études d'Antiquités Africaines).

Le Rider, G. 1966. Monnaies crétoises du Ve au Ier siècle av. J.-C. Paris: Librairie orientaliste P. Geuthner.

Lenormant, F. 1879. La Monnaie dans l'Antiquité. Paris: Rolland et Feuardent libraires editeurs, v. III.

Marengo, S.M. 1991. Lessico delle iscrizioni greche della Cirenaica. Roma: Istituto Italiano per la Storia Antica.

Milne J.G. 1941. Kolophon and its coinage: a study, NNM 96, 1941, pp. 27-113.

Morkholm, O. 1984. The Chronology of the New Style Coinage of Athens, American Numismatic Society Museum Notes, 29, pp.29-42.

Müller, L.; Falbe, C.T.; Lindberg, J.C. 1860. Numismatique de l'Ancienne Afrique. Copenhague: Imprimerie de Bianco Luno.

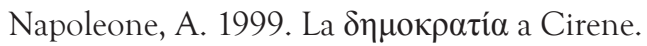
Problemi e prospettive. In AnnAStorAnt 6, 1999, pp. 91-107.

Naville, L. 1951. Les monnaies d'or de la Cyrènaique (de 450 à 250 avant J.-C.). Genève: Atar. 
Pernier, L. 1935. Il tempio e l'altare di Apollo a Cirene : scavi e studi dal 1925 al 1934. Bergamo: Istituto Italiano d'Arti Grafiche.

Platão. Teeteto. Trad. Franco Ferrari. Milano, 2011.

Robert, L. 1966. Monnaies antiques en Troade. Paris: Minard.

Robinson, E.S.G. 1927. British Museum Catalogue of the Greek Coins, Cyrenaica. London: Forni.

SEG IX = Hondius J. J. E. (ed.). 1938. Supplementum Epigraphicum Graecum. Leiden.

SGDI = Colitz H., Bechtel F. (eds.). 1905. Sammlung der Griechischen Dialekt-Inschriften. Göttingen.

Stucchi, S. 1975. Architettura cirenaica. Roma: L'Erma di Bretschneider.
Thompson, M. 1952. The beginning of the Athenian New Style Coinage, American Numismatique Society Museum Notes, 5, pp. 25-33.

Thompson, M. 1961. The New Style Silver Coinage of Athens. Numismatic Studies, 10. New York: American Numismatc Society.

Tucídides. Delle Guerre del Peloponneso, trad. Pietro Manzi, Milano, s/d.

Wallace, W. 1950. Some Eretrians mint magistrates, Phoenix IV, 2, pp. 21-26.

Xenofonte. Memorabili. Trad. Anna Santoni. Milano, 1997. (Classici Greci e Latini.)

Zorat, M. 1990. Atene e il santuario di Ammone, in Hesperia 1, pp. 89-123. 